УДК: 159.923.3:001.82:61

https://doi.org/10.52058/2786-4952 -2021-2(2)-197-207

Сршова-Бабенко Ірина Вікторівна доктор філософських наук, професор, Академік Міжнародної Академії інформатізації ООН, професор кафедри мистецтвознавства i загальногуманітарних дисциплін, Міжнародний гуманітарний університет, вул. Фонтанська дорога, 33, м. Одеса, 65009, тел.: (048) 719-88-38, e-mail: chokaiv@ gmail.com, https://orcid.org/0000-0002-2365-5080

Козобродова Діна Михайлівна кандидат філософських наук, психолог, Кц Альфалогія, вул. Середньофонтанська, 19А, м. Одеса, 65018, тел.: (063) 079-89-61, e-mail: message.od@gmail.com, https://orcid.org/0000-0001-8882-2364

Селіверстова Ганна Сергіївна аспірант кафедри філософії, соціології та менеджменту соціокультурної діяльності, Південноукраїнський національний педагогічний університет імені К.Д. Ушинського, вул. Старопортофранківська 26, м. Одеса, 65000, тел.: (048)753-08-53, e-mail: totolstuj @gmail.com, https://orcid.org/0000-0001-892

\title{
КОНЦЕПТУАЛЬНІ ОСНОВИ ЄДНОСТІ ПЕДАГОГІКИ, ПСИХОЛОГІЇ ТА МЕДИЦИНИ: НАУКА І ЛЮДИНА, ЛЮДСЬКЕ В ЛЮДИНІ- ПОСТНЕКЛАСИЧНА КРИЗА. НАРИСИ ПРО ПОСТНЕКЛАСИКУ. НАРИС-1
}

Головне на світі ие правильно дихати:вдихати щуастя і видихати добро! Народна мудрість

«Сучасна західна ичивілізачія досягла надзвичайних висот в мистецтві розчленування цілого на частини, ... Ми ... нерідко забуваємо зібрати розкладані частини в щось єдине иіле, якими вони колись складались.

Особливо витончену форму мистецтвва розкладання иілого на складові частини прийняло в науиі ». Олвін Тоффлер. Передмова.1984.С. 11.

Анотація. До постнекласики заведено відносити цілий ряд філософських, методологічних i наукових напрямків, які отримали розвиток в останні десятиліття XX ст. і в перші десятиліття XXI ст. В їх число входять синергетика, 
нелінійна динаміка, теорія складності, теорія дисипативних систем, теорія відкритих систем i середовищ, теорія динамічного хаосу i аутопоезис, психосинергетика, альфологія, а також багато інших. Вони включають такі позиції, крізь призму яких і заведено розглядати предмет дослідження в річище ідей i уявлень постнекласики. Постнекласика розмірковує в рамках такої термінології як філософські підстави синергетики [1] та ii загальнонауковий статус [2], концептуальні підстави цілісності «ціле-в-цілому» [3] і культурної політики [4], психосинергетичний концепт психомірних середовищ в житті людини в їх єдності / цілісності від народження«(мозок-психіка) особистість ...» як нелінійних, коли неврівноваженість є умовою існування [5;6], а хаос грає продуктивну роль [7], і т. д. Це також синергетична парадигма і методологія, епістемологічні принципи синергетики, самоорганізація часу і простору, в тому числі одночасно [8], соціальна самоорганізація [9], еволюційна партитура, взаємодія предметних знань, математичного моделювання і практичної філософії [10], час синергетики (В. І. Аршинов) і психосинергетичні стратегії людської діяльності, концептуальна модель (філософська категорія) «ціле-в-цілому / ціле в цілому», що включає цілісність, нелінійність і складність концепту «(brainpsyche) mind / consciousness ...» [«(bp) $\mathrm{m} / \mathrm{c} . . »][3,11,5$, 6, c. 103-108], самоорганізована критичність, логіка нелінійної динаміки [12], еволюційна епістемологія, синергетичний світ що конструюється [14], синергетичний підхід до систем / середах різної природи що самоорганізуються [13], «режим із загостренням»[14]. Психосинергетика крізь призму явищ «психомірність», «психомірні середовища» та демонстрації нелінійності їхньої поведінки з позиції «порядок через хаос» прагне скоротити проріз між термінологічною та світоглядною реальністю постнекласичної науки, з одного боку, і практикою освіти, психології та медицини в аспекті людини, з іншого.

Ключові слова: психосинергетика, психомірність, самоорганізація, хаотизація, постнекласика.

Yershova-Babenko Irina Viktorivna Doctor of Philosophy, Professor, Academician of the International Academy of Informatization of the United Nations, professor of the Department of Art History and General Humanities, International Humanities University, Fontans'ka doroha St., 33, Odessa, 65009, tel.: (048) 719-8838, e-mail: chokaiv@gmail.com, https://orcid.org/0000-0002-2365-5080

Kozobrodova Dina Mykhaylivna PhD, psychologist, Alphalogy Counseling Center, Srednefontanskaya St., 19A, Odessa, 65018, tel.: (063) 079-89-61, e-mail: message.od@gmail.com, https://orcid.org/0000-0001-8882-2364

Seliverstova Hanna Serhiyivna PhD postgraduate, Department of Philosophy, Social Studies and Socio-Cultural Activity Management, South Ukranian National Pedagogical University named after K.D. Ushynsky, Staroportofrankivs'ka St., 26, Odessa, 65000, tel.: (048)753-08-53, e-mail: totolstuj@gmail.com, https//orcid.org/0000-0001-892 


\section{CONCEPTUAL FUNDAMENTALS OF THE UNITY OF PEDAGOGY, PSYCHOLOGY AND MEDICINE: SCIENCE AND HUMAN, HUMAN IN MAN - POST-CLASSICAL CRISIS.FEATURE ARTICLE ABOUT POST-CLASSICS. FEATURE ARTICLE -1}

The main thing in the world - it is correct to breathe: $\quad$ breathe happiness and breathe good!

Folk wisdom

"Modern Western civilization has reached extraordinary heights in the art of dismemberment whole in parts, ... We ... often forget assemble the decomposed parts into something whole, as they once consisted. Especially elegant art form decomposition of the whole into constituent parts took in science ". Alvin Toffler. Preface.1984. S. 11.

Abstract. The post-non-classics include a number of philosophical, methodological and scientific areas that have developed in the last decades of XX century. and in the first decades of the XXI century. These include synergetics, nonlinear dynamics, complexity theory, dissipative systems theory, open systems and environments theory, dynamic chaos theory and autopoiesis, psychosynergetics, alphology, and many others. They include such positions, through the prism of which it is customary to consider the subject of research in the stream of ideas and ideas of the post-nonclassic.

Post-classicism thinks in terms of such terminology as philosophical foundations of synergetics [1] and its general scientific status [2], conceptual foundations of integrity "as a whole" [3] and cultural policy [4], psychosynergetic concept of psychomeric environments in human life in their unity / integrity from birth "( brainpsyche) personality ... "as nonlinear, when imbalance is a condition of existence $[5 ; 6]$, and chaos plays a productive role [7], etc. It is also a synergetic paradigm and methodology, epistemological principles of synergetics, self-organization of time and space, including simultaneously [8], social self-organization [9], evolutionary score, interaction of subject knowledge, mathematical modeling and practical philosophy [10], time of synergetics (VI Arshinov) and psychosynergetic strategies of human activity, conceptual model (philosophical category) "whole-in-whole / whole in general", which includes integrity, nonlinearity and complexity of the concept "(brainpsyche) mind / consciousness ..." ["(bp) m / c ..."] [3, 11, 5, 6, p. 103-108], selforganized criticality, logic of nonlinear dynamics [12], evolutionary epistemology, constructed synergetic world [14], synergetic approach to self-organizing systems / environments of different nature [13], "sharpened mode" [14]. 
Psychosynergetics through the prism of the phenomena of "psychomerism", "psychomeric environments" and demonstrations of nonlinearity of their behavior from the standpoint of "order through chaos" seeks to reduce the gap between terminological and ideological reality of post-classical science, on the one hand, and the practice of education, psychology and medicine. on the other.

Keywords: psychosynergetics, psychomerism, self-organization, chaos, postnonclassicism.

Постановка проблеми. У статті у світлі психосинергетики розглядається проблема розриву цілісності середовища людини й хаотизації його психомірності у всіх сферах реальності сьогодні. Ставиться питання про необхідність розглядати освітню, психологічну, соціальну та медичну реальності в сукупності як єдність, цілісність, засновану на іiі адекватності психомірності людини. Теоретико-методологічною підставою щодо такої «сукупної реальності» i психомірності одночасно розглядається концептуальна модель (філософська категорія) «ціле-в-цілому», концепт «bpm / с ...») - «мозок-психіка-розум / розум / свідомість ...» i однойменна теорія $[3, \quad 11, \quad 5, \quad 6, \quad$ с. $103-108]]$. Дана проблема пов'язана з рівнем концептуальності кризи наукового знання в його постнекласичному контексті та місцем людини, що формується у новій картині світі «цифро-суб'єкта» i «цифро-соціуму» [6, с. 43-52]. Особливо відчутним це стало для гуманітарного та медичного знання в принципово нових умовах життя людини - безперервної хаотизації через надшвидку й непередбачувану зміну соціально-психолого-інформаційної реальності. Питання зачіпає психомірність сфери освіти (педагогіка, психологія) і медицини, демонструючи небезпеку певних технологій для людини.

\section{Підстави єдності освіти, психології та медицини крізь призму «людського в людині».}

Що об'єднує, 3 одного боку, названі сфери - педагогіка, психологія, медицина, а з іншого - постнекласичну науку в «особі» психосинергетики, а також вхидни до іiі предмета явища «психомірне середовище», «психомірність»[3], « психомірність соціальної реальності » [15] і« хаотизація психомірності соціальної реальності»[16].

Перш за все, те, що в кожному випадку мова йде про людину, зокрема, в даній статті акцент зроблено на людське в людині, на проблемі людино і нелюдиномірності (Єршова-Бабенко), психомірності людського суспільства.

По-друге, те, що об'єднує концептуальною підставою виступає концепт «(bp) m / c ...» і концептуальна модель «нелінійне ціле-в-нелінійному цілому», що включає цілісність і складність; те, що і мозок, і психіка, і особистість людини за визначенням класифікуються в постнекласики як відкриті нелінійні середовища / системи що самоорганізуються. Це дозволяє розглядати поведінку названих «гравців» в одній парадигмі, з огляду на продуктивну роль випадковості та хаосу, порушення симетрії в часі та просторі, в тому числі одночасно.

По-третє, те, що у функціонуванні мозку має місце невисока швидкість (в порівнянні з комп'ютером) при більш високій ефективності у вирішенні завдань, 
а також діє нелінійний зворотний зв'язок в гіпербагатошаровому середовищі нейронів (синапси, глія). Це, давно відома нейрофізіологам якість мозку, по задуму поширюється на його (мозок) продукти в різних видах психічної діяльності, їх емоціоэмкості, смисло- і цінністноэмких - процесах, потоках і / або події психічного характеру (особистості, мисленні, ...) у людини. Але до цього часу соціо-інформаційні зусилля і психо-соціо-інформаційна увага фахівців залишається «сліпа» до цього факту, як і раніше адресуючи до збільшення швидкості як єдиному шляху збільшення ефективності.

По-четверте, допустимість однотипності (моделі / ступеня) порушення, компенсації та наслідків поведінки «гравців» концепту «bpm / c ..» при високошвидкісній мінливості умов (інформаційних, соціальних). Наприклад, поведінка, виражена дифузним характером пошкодження зв'язків на різних рівнях - ментальному, інформаційному, соціальному, нейрологічному та ін.[17,18,5].

По-п'яте, ступінь порушення аспекту психомірності аж до появи ефекту «критичного порога» / «критичної різниці» / «критичного значення» (I. Пригожин, Г. Хакен). У цьому випадку мова про порушення симетрії (по Пригожину), а в психосинергетиці цього аспекту в стані людини або в стані психомірного середовища, психомірного продукту людської діяльності на рівні соціуму, навчання, індивідуальної творчості та ін.

В обох випадках мова йде про певну критичність як деякому критичному стані, деякої критичної точки, якою досягають системи / середовища у своїх станах, які висловлюються обраними показниками. У цій інтерпретації саме критичність порога або різниці - досягнення системою цієї точки різниці, призводить до якісного стрибка в стані або поведінці системи / середовища. Показниками можуть бути, наприклад, температура як в разі термодинаміки (I. Пригожина), хвиля як в разі синергетики (Хакена). У нашому випадку щодо даної в психосинергетики ПС - це особистісна оцінка і, як наслідок, потреба; ціннісна позиція і, як наслідок, невідповідність потреби, наприклад, в зміні, що ближче до вибору системої флуктуації; традиція в культурі, емоція, вчинок, інформація, їх швидкісна, ємністно-структурна, процесуально-потокова та інші характеристики.

По-шосте, фрактальність моделі високошвидкісних змін умов. Нині мова йде про рівень високошвидкісних соціально-інформаційних, медикопсихологічних і освітніх умов, коли відбувається часта і кардинальна зміна умов життя людини і його психічного стану через карантин, щеплення, обмеження, що обумовлені епідемією.

Поняття «фрактали», «фрактальні» об'єкти є одним 3 «власних», «особливих» понять синергетики. Початково в математиці визначаються як множини, які мають властивість самоподібності, масштабної інваріантності, тобто малий фрагмент структури фрактального об'єкта подібний до іншого, більш великому фрагменту або навіть структурі в цілому [19].

У психосинергетики воно отримало розширення в аспекті психомірності в поєднанні 3 нейрофізіологією мозку в умовах високошвидкісної травми 3 дифузним характером пошкодження аксонів, рухової та особистісної 
систем $[17,18]$. Фрактальність має на увазі подібність фігур, станів і процесів в просторі, часу, сприйнятті та характеризує психомірні середовища / системи.

По-сьоме, можливість отримувати позитивні результати при проведенні медико-психолого-реабілітаційних та навчально-корекційних, розвивальних заходів з методу «Створююча Сила» і методик та технологій, що входять до нього («Видалення зайвого», «АНДР», «ОПВЦ», « 10x10»,« ПЧК »). [17, 20, 21, 22]

Ілюстрацією або прикладом-аналогом може бути порушення на рівні ціннісних та особистісних зв'язків у ставленні людини до себе і свого здоров'я, до сім'ї, до роботи, до навчання. Це дозволяє розглянути модель дії / протікання / розгортання психічно особистісно і стресо-орієнтованого перевантаження, що набуває, фактично, форму особливого типу травми 3 дифузним характером пошкодження зв'язків [17]. Критична різниця, що спрацьовує в таких випадках, наприклад, між швидкістю процесів в середовищі / умовах на різних іiі рівнях i / або в цілому є маркером сформованості точки неврівноваженого переходу нового типу, що виражає факт виникнення панічного стану [23].

\section{Явища «психомірне середовище» (ПС), «психомірність», нестійкість і незворотність}

Психомірні системи / середовища (ПС) виділені та розглядаються в психосинергетиці [24] як широкий спектр продуктів, похідних від системо / середовоутворюючої функції психіки людини - гіперсистеми синергетичного порядку. У тому числі мова йде про прийняті у вітчизняній традиції (по Платонову) складових психіки - особистості, мислення, сприйняття, пам'яті та ін. Звідси випливає явище психомірності як характеристики цих продуктів, що вимагає врахування при їх дослідженні.

Під психомірністью (психомірними середовищами) маються на увазі

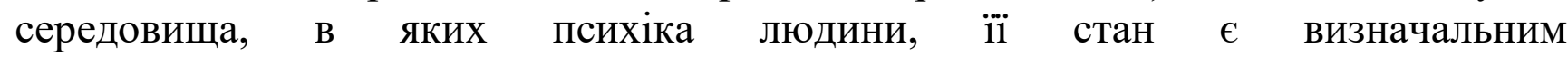
фактором, параметром порядку, автором i користувачем всього розумового багатства, яким людина володіє, - розуму, знань, особистості, а також продуктів розумової (психічної) діяльності людини. Вони присутні в соціальній, освітній та інших людиномірних середовищах $[3,11,5]$.

Річ у тім, що у світі психомірної нестійкості та еволюції до нових організованих структур, до нової організованої складності, коли ПС перебуває в украй нерівноважному стані, вирішувати іiі «долю» можуть дуже малі події / флуктуації, події / фактори, на які зазвичай, тобто в стійкому стані, це середовище не реагує. Тому люди й не звертають уваги на подібні «сплески», не враховуючи стан ПС у відповідний період (стадія, фаза). Вони можуть або не знати про це, або не мати можливості визначити це. У підсумку вважають, що ці події можуть «начебто» ніяк не бути пов'язаними з даної середовищем і / або ситуацією. Не випадково в підручнику «Нерівноважна термодинаміка» I. Пригожин звертає увагу на те, що навіть в умовах експерименту - це фактори, часто виходять за експериментальний контроль.

При дослідженні ПС очевидно, що вкрай нерівноважний стан грає найважливішу роль в поведінці психомірних середовищ. Для подальшого 
розуміння важливості особливостей вкрай нерівноважного стану в поведінці ПС необхідно позначити та по можливості розкрити деякі поняття, незвичні для гуманітаріїв.

Наприклад. Як відомо, існує загальний принцип для лінійного режиму, відповідно до стаціонарного стану в цьому режимі $\epsilon$ такі стани, в яких повне виробництво ентропії (міри порядку) досягає мінімуму. Ця вимога також забезпечує стійкість стаціонарного стану.

Однак, в далекому від рівноваги нелінійному режимі настільки загальний принцип визначення стану системи / середовища відсутній. Отже, стан розглянутих в психосинергетики середовищ - ПС та інших, далеких від рівноваги, можуть бути нестійкими та переходити до нових організованих станів в результаті власного впливу на самих себе всередині себе. Причому, це може проявлятися як в одному 3 параметрів або вимірювань ПС, так і в багатьох 3 них як локально, так і на макрорівні в цілому на рівні ПС як нелінійної цілісності. Нарешті, можливий і режим на рівні «нелінійного цілого в нелінійному цілому».

Інший приклад, припустимо, що кожне $\mathrm{X}^{\mathrm{i}}$ представляє якись інформаційний стан ПС. Відхилення від інформаційної рівноваги характеризує параметр « дельта $^{\mathrm{i}}$ ». Коли дельта ${ }^{\mathrm{i}}$ дорівнює нулю, ПС знаходиться в стані інформаційної рівноваги. Коли дельта ${ }^{\mathrm{i}}$ мало, ПС знаходиться поблизу інформаційнї рівноваги, наближаючись до неї. Це сімейство станів, що виражає безперервне розширення рівноважного стану, I. Пригожином для термодинамічних систем було названо термодинамічною гілкою. За аналогією сімейство станів, що виражають безперервне розширення рівноважного інформаційного стану ПС, назвемо нелінійної інформаційно-динамічною гілкою ПС. Тоді, за визначенням, в деяких ПС, таких, як внутріпсихічні реакції типу автокаталітичних інформаційного рівня, коли дельта ${ }^{\mathrm{i}}$ досягає критичного значення, виникають стани, що належать такому типу гілки, і вони стають нестійкими. В цьому випадку ПС переходить на нову гілку, яка може відповідати організованим структурам. Ці структури або організація структур можуть бути заздалегідь підготовлені та ПС тільки підводять до них. Однак, звертає на себе увагу наступне. «У певному сенсі крайнім випадком нестійких систем є« хаотичні системи », для яких опис в термінах траєкторій стає недостатнім, оскільки траєкторії, спочатку як завгодно близькі, $з$ часом експоненціально розходяться. ... Хаос з'являється також при вивченні макроскопічних необоротних процесів ... »[7, с. 7]. У нашому випадку такими процесами є концепт «bpm / c ..» і цілісність сфер «освіти (педагогіка), психологія та медицина».

Коли умова «дельта дорівнює нулю» порушується, інформодінамічна гілка може стати нестійкою. Якщо вона стає нестійкою, ПС може перейти на нову гілку, яка в загальному випадку являє собою організовані структури, або які були в пам'яті, в досвіді, тезаурусі, або штучно новостворювані, щоб вивести ПС на інший шлях розвитку щодо можливого спектра шляхів, наявного в пам'яті ПС.

\section{Явище «психомірність соціальної реальності» і проблема її хаотизації}

В контексті психосинергетики питання психомірності соціальної реальності i iï хаотизації досліджений в роботах (козобр селів). 
До теперішнього часу показано вплив психомірності на нестійку поведінку соціальних середовищ в процесах соціальної самоорганізації, а також особлива роль психомірності особистості в характері подібної нестійкої поведінки власне соціального середовища. Обгрунтовано застосування концепту «психомірність соціальної реальності» (Козобродова) i розглянута роль самоорганізованих структур в поведінці нерівноважних соціо-гуманітарних процесів [ 25, 15].

Дослідження хаосу показало особливу роль «соціального хаосу» в аспекті психомірності соціальної реальності [16]. 3 метою подальшого розгляду питання введений концепт «хаотизації психомірності соціальної реальності» (Селівёрстова), що дозволило показати місце хаосу в поведінці явища, вираженого концептом «bpm / c». Тим самим зробити наступний крок у розширенні сегмента присутності поняття «хаос» в гуманітарному знанні кінця ХХ ст. і в переході на відповідний рівень дослідження такої складності [26].

Висновки. Таким чином, в нових умовах необхідне введення концепту «психолого-освітньо-медична цілісність» як сукупне зовнішне психомірне середовище - психомірна соціальна реальність нового типу, 3 одного боку, i внутріпсихічне / внутріособистісне середовище людини як психомірна суб'єктивна реальність, тобто його фактична реальність, в якій він подумки «живе» і в якій він представляє зовнішнє середовище у своїй пам'яті, але вже в певній індивідуальній редакції. У даній роботі показана важливість їх дослідження в термінах і з позиції постнекласичної науки, розгляду ролі ступеня порушення симетрії різного рівня в кожній і між ними. Підкреслюється, що виділені сукупні цілісності не ідентичні. Кожна 3 них виступає нелінійної, макроскопічної, а з позицій психомірною - незворотною, що вимагає адекватності та коректності дослідних i технологічних процесів 3 метою збереження людського в людині. Також виділені концепти «психомірність соціальної реальності» i ii хаотизація. концептуальною підставою подібної єдності (цілісності) розглядається психосинергетичний підхід i розроблені в ньому концептуальна модель «ціле-в-цілому», що отримала впровадження, що включає цілісність, складність, незворотність і нелінійність, концепт «bpm / c ..» i однойменна теорія, метод «Створююча Сила »і входять до нього методики, які отримали підтвердження.

\section{Лimepamypa:}

1. Степин, В. С. Философское основание синергетики [Электронный ресурс]. Режим доступа: http://spkurdyu- mov.ru/philosophy/o-filosofskix-osnovaniyax-sinergetiki-v-s- stepin

2. Добронравова И.С. Синергетика: становление нелинейного мышления. - К.: Либидь, 1990. - 230 с.; Она же: Практическая философия науки / Ирина Добронравова. - Сумы: Университетская книга, 2017. - 352 с.

3. Ершова-Бабенко И.В. Психосинергетические стратегии человеческой деятельности. Концептуальная модель: монография / И.В. Ершова-Бабенко. - В.: KNYGA NOVA, 2005. - 368 с.

4. Астафьева О. 2009. Целостность культуры как “единство множественности" / Синергетическая Парадигма. Социальная синергетика. М.: Прогресс-Традиция, С. 133- 156.

5. Єршова-Бабенко I.В. Психосинергетика: монографія / I. В. Єршова-Бабенко. - Херсон: вид-во Гринь Д.С., 2015. - 488c. 
6. Ершова-Бабенко И.В. Психосинергетика: методологический статус, теория и практика: юбилейный сборник научных трудов профессора И. В. Ершовой-Бабенко / ред.-сост. В. Б. Ханжи, Н. В. Кривцова. - Одесса : Фенікс, 2020. - 256 с.

7. Пригожин И., Стенгерс И. Время, хаос, квант. К решению парадокса. М.: Едиториал УPCC, 2003. - $240 \mathrm{c}$

8. Хакен, Г. (2001) Принципы работы головного мозга: Синергетический подход к активности мозга, поведению и когнитивной деятельности. M.: PerSe, 353 с.

9. Бевзенко Л.Д. Социальная самоорганизация. Синергетическая парадигма: возможности социальных интерпретаций. - К.: Институт социологии НАН Украины, 2002. - 437 с.

10. Буданов В. Г. Методология синергетики в постнекласической науке и в образовании. Монография - М.: Издательство ЛКИ,2007. — 232 с. (Синергетика в гуманитарных науках).

11. Ершова-Бабенко И.В. Место психосинергетики в постнеклассике. Постнеклассика: философия, наука, культура. Отв.ред.Л.П, Киященко, В.С. Степин. СПб.: 2009, С.460-490

12. Г. Г. Малинеикий, А. Б. Потапов, А. В. Подлазов / Нелинейная динамика : подходы, результаты, надежды. - Москва : URSS : КомКнига, печ. 2006. - 279 с.

13. Хакен Г. Синергетика : монография / Г. Хакен. - М. : Мир, 1980. - 404 с.

14.Князева Е.Н., Курдюмов С.П. Синергетика как новое мировидение: диалог с И. Пригожиным // Вопросы фи- лософии. - 1992. - No 12. - С. 3-20.

15. Ершова-Бабенко И. В., Козобродова Д. М. Психомерность социальной реальности в аспекте самоорганизации как предмета социально-философского и психосинергетического анализа. Монография. / Ершова-Бабенко И. В. - Одесса: Бондаренко М. А., 2020 - 162с.

16. Ершова-Бабенко И.В., Селиверстова А.С. 2020. Хаотизация психомерности социальной реальности: социально-философский и психосинергетический контекст: монография / Одесса: Украинское синергетическое общ-во, Бондаренко М.А., 196с.

17. Ершова-Бабенко И. В. Методологические проблемы разработки теории психики в русле постнеклассических практик / И. В. Ершова-Бабенко // Постнеклассические практики : определение : материалы Междунар. междис- циплинар. семинара. - М. : МАКС Пресс, 2008. C. 226- 236 .

18. Ершова-Бабенко И. В. Постнеклассическая методология - психосинергетика в решении актаульных задач медико- психологической реабилитации / И. В. Ершова-Бабенко // Вісник Харківського національного університету ім. В.Н. Каразіна. - 2012. - Вип. 49. - С. 169175. - (Сер. Психологія.)

19. Князева, Е.Н., Курдюмов, С.П. (1994) Законы эволюции и самоорганизации сложных систем. М.: Наука, 236 с.

20. Ершова-Бабенко, И.В., \& Горищак, С.П., Енин, Р.В. (2012) Постнеклассическая методология - психосинергетика: возможности применения в медицине. Інтегративна антропологія. № 1. С. 10-24.

21. Мадінова Ю. І. Особливості дезадаптації студентів-медиків- а/реф., канд. псих. наук Одеський Національний Університет Імені I. I. Мечникова, 2016. 18 с.

22. Кривцова Н.В. Психологічні особливості потенціалу самореалізації особистостіa/peф. канд. псих. наук - Одеський Національний Університет Імені I. I. Мечникова, 2018. 22 с.

23. Ершова-Бабенко И. В., Топор В. П., Сухин Ю. В., Решетняк В. В., Гуриенко А, В., Бабенко Д. Л., Чемересюк И., Корниенко С. В., Медянова Е. В. Проблема психологи- ческой реабилитации при политравме // И. В. Ершова- Бабенко, В. П. Топор и др. // Медицина. — No 3, 2008. - C. 53-61.

24. Сршова-Бабенко І.В. (1992). Методологія дослідження психіки як синергетичного об'єкта. Монографія. Одеса: ОДЕК, 124с.

25. Козобродова Д. М. 2019 Роль самооорганизующихся структур в поведении неравновесных социо-гуманитарных процессов в контексте гипертеории «brainpsyche-mind / consciousness» // Международная научная конференция "Концепти соціокультурної трансформації сучасного суспільства”, ПНПУім. К.Д.Ушинського. Одеса, 24 травня 2019p. 
26. Селиверстова А.С. 2019. Место хаоса и самоорганизации в феномене, выраженном концептом "BRAIN- PSYCHE-MIND / CONSCIOUSNESS" // Международная научная конференция "Концепти соціокультурної трансформації сучасного суспільства", ПНПУім. К.Д.Ушинського. Одеса, 24 травня 2019p.

\section{References:}

1. Stepin, V.S. (n.d.). Filosofskoe osnovanie sinergetiki [Philosophical basis of synergetics]. spkurdyumov.ru. Retrieved from http://spkurdyumov.ru/philosophy/o-filosofskix-osnovaniyaxsinergetiki-v-s-stepin/ [in Russian].

2. Dobronravova, I.S. (2017). Prakticheskaia filosofiia nauki [Practical philosophy of science]. Sumy: Universitetskaia kniga [in Russian].

3. Ershova-Babenko, I.V. (2005). Psikhosinergeticheskie strategii chelovecheskoii deiatelnosti Kontseptualnaia model [Psychosynergetic strategies of human activity. Conceptual model]. Vinnitsa: KNYGA NOVA [in Russian].

4. Astafeva, O. (2009). Tselostnost kultury kak "edinstvo mnozhestvennosti" [The integrity of culture as "unity of plurality"]. Sinergeticheskaia Paradigma. Sotsialnaia sinergetika - Synergetic Paradigm. Social synergy. (pp. 133-156). Moscow: Progress-Traditsiia [in Russian].

5. Yershova-Babenko, I.V. (2015). Psykhosynerhetyka [Psychosynergetics]. Kherson: vydvo Hryn D.S. [in Ukrainian].

6. Ershova-Babenko, I.V. (2020). Psikhosinergetika: metodologicheskii status, teoriia i praktika [Psychosynergetics: methodological status, theory and practice]. V. B. Khanzhi, N. V. Krivtsova (Eds.). Odessa: Feniks [in Russian].

7. Prigozhin, I., Stengers, I. (2003). Vremia, khaos, kvant. K resheniiu paradoksa [Time, chaos, quantum. Towards a solution to the paradox]. Moscow: Editorial URSS [in Russian].

8. Khaken, G. (2001). Printsipy raboty golovnogo mozga: Sinergeticheskii podkhod $k$ aktivnosti mozga, povedeniiu i kognitivnoi deiatelnosti [Principles of the Brain: A Synergistic Approach to Brain Activity, Behavior, and Cognitive Performance]. Moscow: PerSe [in Russian].

9. Bevzenko, L.D. (2002). Sotsialnaia samoorganizatsiia. Sinergeticheskaia paradigma: vozmozhnosti sotsialnykh interpretatsii [Social self-organization. Synergetic Paradigm: Possibilities of Social Interpretations]. Kyiv: Institut sotsiologii NAN Ukrainy [in Russian].

10. Budanov, V.G. (2007). Metodologiia sinergetiki v postneklasicheskoi nauke $i v$ obrazovanii [Methodology of synergetics in post-nonclassical science and education]. Moscow: Izdatelstvo LKI [in Russian].

11. Ershova-Babenko, I.V. (2009). Mesto psikhosinergetiki v postneklassike [The place of psychosynergetics in post-nonclassics]. Postneklassika: filosofiia, nauka, kultura - Post-nonclassics: philosophy, science, culture. L.P. Kiiashchenko, V.S. Stepin (Eds.). (pp. 460-490). Saint Petersburg [in Russian].

12. Malinetskii, G.G., Potapov, A.B., Podlazov, A.V. (2006). Nelineinaia dinamika: podkhody, rezultaty, nadezhdy [Nonlinear dynamics: approaches, results, hopes]. Moscow: URSS: KomKniga [in Russian].

13. Khaken, G. (1980). Sinergetika [Synergetics]. Moscow: Mir [in Russian].

14. Kniazeva, E.N., Kurdiumov, S.P. (1992). Sinergetika kak novoe mirovidenie: dialog s I. Prigozhinym [Synergetics as a new worldview: dialogue with I. Prigozhin]. Voprosy filosofii Problems of Philosophy, 12, 3-20 [in Russian].

15. Ershova-Babenko, I.V., Kozobrodova, D.M. (2020). Psikhomernost sotsialnoi realnosti v aspekte samoorganizatsii kak predmeta sotsialno-filosofskogo i psikhosinergeticheskogo analiza [Psycho-dimensionality of social reality in the aspect of self-organization as a subject of sociophilosophical and psychosynergetic analysis]. Odessa: Bondarenko M. A. [in Russian].
16.
Ershova-Babenko,
I.V.,
Seliverstova,
A.S.
(2020). Khaotizatsiia psikhomernosti sotsialnoi realnosti: sotsialno-filosofskii $i$ psikhosinergeticheskii 
kontekst [Chaotization of the psycho-dimensionality of social reality: socio-philosophical and psychosynergetic context]. Odessa: Ukrainskoe sinergeticheskoe obshch-vo, Bondarenko M.A. [in Russian].

17. Ershova-Babenko, I. V. (2008). Metodologicheskie problemy razrabotki teorii psikhiki v rusle postneklassicheskikh praktik [Methodological problems of the development of the theory of the psyche in line with post-non-classical practices]. Postneklassicheskie praktiki: opredelenie - Postnon-classical practices: definition: Proceedings of the International Interdisciplinary Seminar. (pp. 226-236). Moscow: MAKS Press [in Russian].

18. Ershova-Babenko, I. V. (2012). Postneklassicheskaia metodologiia - psikhosinergetika v reshenii aktaulnykh zadach mediko-psikhologicheskoi reabilitatsii [Post-nonclassical methodology psychosynergetics in solving the actual problems of medical and psychological rehabilitation]. Visnik Kharkivskoho natsionalnoho universitetu im. V.N. Karazina - The Journal of V. N. Karazin Kharkiv National University, 49, 169-175 [in Russian].

19. Kniazeva, E.N., Kurdiumov, S.P. (1994) Zakony evoliutsii $i$ samoorganizatsii slozhnykh system [The laws of evolution and self-organization of complex systems]. Moscow: Nauka [in Russian].

20. Ershova-Babenko, I.V., Gorishchak, S.P., Enin, R.V. (2012) Postneklassicheskaia metodologiia-psikhosinergetika: vozmozhnosti primeneniia $\mathrm{v}$ meditsine [Post-nonclassical methodology - psychosynergetics: potential applications in medicine]. Integrativna antropologiia Integrated anthropology, 1, 10-24 [in Russian].

21. Madinova, Yu. I. (2016). Osoblyvosti dezadaptatsii studentiv-medykiv [Features of maladaptation of medical students]. Extended abstract of candidate's thesis. Odesa: Odeskyi Natsionalnyi Universytet Imeni I. I. Mechnykova [in Ukrainian].

22. Kryvtsova, N.V. (2018). Psykholohichni osoblyvosti potentsialu samorealizatsii osobystosti [Psychological features of the potential of self-realization of the individual]. Extended abstract of candidate's thesis. Odesa: Odeskyi Natsionalnyi Universytet Imeni I. I. Mechnykova [in Ukrainian].

23. Ershova-Babenko, I. V., Topor, V. P., Sukhin, Iu. V., Reshetniak, V. V., Gurienko, A. V., Babenko, D. L., et al. (2008). Problema psikhologicheskoi reabilitatcii pri politravme [The problem of psychological rehabilitation in polytrauma]. Meditcina-Medicine, 3, 53-61 [in Russian].

24. Yershova-Babenko, I.V. (1992). Metodolohiia doslidzhennia psykhiky yak synerhetychnoho obiekta [Methodology of research of psyche as synergetic object]. Odesa: ODEK [in Ukrainian].

25. Kozobrodova, D. M. (2019). Rol samooorganizuiushchikhsia struktur v povedenii neravnovesnykh sotcio-gumanitarnykh protcessov $\mathrm{v}$ kontekste giperteorii «brain-psychemind / conssiousness» [The role of self-organizing structures in the behavior of non-equilibrium socio-humanitarian processes in the context of the "brain-psyche-mind / consciousness" hypertheory]. Kontsepty sotsiokulturnoi transformatsii suchasnoho suspilstva - Concepts of sociocultural transformation of modern society : Proceedings of International scientific conference. Odesa: PNPUim. K.D.Ushynskoho [in Ukrainian].

26. Seliverstova, A.S. (2019). Mesto khaosa i samoorganizatcii v fenomene, vyrazhennom kontceptom "brain-psyche-mind / consciousness" [The place of chaos and selforganization in the phenomenon expressed by the concept "brain-psyche-mind / consciousness"]. Kontsepty sotsiokulturnoi transformatsii suchasnoho suspilstva - Concepts of socio-cultural transformation of modern society : Proceedings of International scientific conference. Odesa: PNPUim. K.D.Ushynskoho [in Ukrainian]. 